УДК 658:65.011.55

DOI: https://doi.org/10.37320/2415-3583/12.18

Захарчин Г.М.

доктор економічних наук, професор,

Національний університет «Львівська політехніка» ORCID: https://orcid.org/0000-0002-4081-7926

Любомудрова Н.П.

кандидат економічних наук, доцент,

Національний університет «Львівська політехніка» ORCID: https://orcid.org/0000-0002-1982-0442

Панас Я.В.

кандидат економічних наук,

Національний університет «Львівська політехніка» ORCID: https://orcid.org/0000-0003-4520-9273

\title{
ОСНОВНІ АСПЕКТИ УПРАВЛІННЯ ЗНАННЯМИ В СУЧАСНИХ УМОВАХ
}

Охарактеризовано основні аспекти управління знаннями в умовах су-часної реальності, до яких віднесено: ідеологічний, організаційний, технологічний, культурологічний, інституційний. В окрему групу виділено методологічний аспект для систематизаиї основних понять і впорядкування категоріального апарату, а також для чіткого окреслення предмета вивчення як окремої галузі знань. Акиентовано на факторах, які підсилюють увагу до необхідності активного використання знань для інноваџійного поступу суспільства. Підкреслено важливість системного поєднання теоретичних аспектів дослідження із практикою, оскільки таким чином досягається трансформація знання в інтелектуальний потенціал організації та підвищується ї̈ інноваційна спроможність. Виділено особливості управління знаннями на всіх стадіях його життевого ичиклу із зазначенням домінуючих методів і моделей управління знаннями. Наголошено на необхідності активізації процесів створення інтелектуальних організацій, здатних примножувати і створювати нові знання.

Ключові слова: знання, управління знаннями, генерування знань, моделі управління знаннями, інноваційність, компетениії, інтелектуалізація.

Постановка проблеми. Інтелектуалізація і цифровізація економіки та суспільства, поширення високих технологій, нанотехнологій і метатехнологій за одночасного скорочення життєвого циклу технологічних інновацій, зростання цінності інтелектуальних активів та вартості знань, зародження кіберфізичного простору ці та інші глобальні процеси у своїй сукупності відображають нові закономірності перебігу економічних трансформацій, зумовлюють зміни в соціально-економічному житті й окреслюють нові завдання. Сучасні виклики актуалізують проблему пошуку та переосмислення джерел економічного зростання і підвищення конкурентоспроможності підприємств. Оскільки сьогодні успішні корпорації світу, які $\epsilon$ інноваційними лідерами, стратегічно зорієнтовані на розвиток економіки знань, то питання управління знаннями стає пріоритетним.

Однак є протиріччя між необхідністю розвивати цю галузь знання та відсутністю реальної стратегії та ефективних механізмів управління знаннями в діяльності вітчизняних підприємств. У цьому контексті визначення місця управління знаннями у структурі сучасних напрямів наукових досліджень і доведення завдань управління знаннями до практичної реалізації $\epsilon$ основною віссю проблеми. Зазначена проблематика повинна вирішуватися системно, одночасно на теоретичному й практичному рівнях, оскільки тільки завдяки поєднанню теоретичних аспектів дослідження із практикою досягається трансформація знання в інтелектуальний потенціал організації та підвищується іiі інноваційна спроможність.

Аналіз останніх досліджень і публікацій. Побудова економіки знань не тільки зумовила структурні зміни в суспільстві, але й спонукала до появи цікавих наукових досліджень, у яких науковці під різним кутом зору вивчають, аналізують, осмислюють і узагальнюють цю реальність. Заслуговує на увагу концептуальний підхід до окресленої проблематики в контексті поєднання засадничих основ інтелектуалізації суспільства, інформатизації та розвитку національної економіки, запропонований науковцями у монографічних виданнях [1]. Теоретичні аспекти управління організаційними знаннями та особливості стратегічного управління знаннями доволі повно висвітлюють наукові джерела $[4 ; 5 ; 10]$. Культурологічний підхід у системі управління знаннями через призму інтелектуальної культури наведено в авторській статті [2]. Управління знаннями в системі інноваційного розвитку організації та розгляд їх як конкурентної переваги висвітлюють наукові публікації [3; 7]. Прикладні аспекти управління знаннями, зокрема технології та моделі управління знаннями, в широкому діапазоні представлені публікаціями вітчизняних та зарубіжних авторів $[6 ; 9 ; 11 ; 12]$.

Однак залишаються не до кінця вирішені питання, які б давали цілісне уявлення про управління знаннями і системно висвітлювали всі його багатогранні аспекти. 3 огляду на це, пропонована стаття покликана частково заповнити цю прогалину.

Мета статті полягає у висвітленні важливих аспектів управління знаннями в сучасних умовах, які поглиблюють засадничі основи розгляду знання як категорії та відображають прикладні технології управління знаннями.

Виклад основного матеріалу. Нова соціально-економічна реальність не тільки окреслює нові правила 
організації економічного простору, взаємодії суб'єктів у цьому просторі, але й диктує нові вимоги до забезпечення їхнього успішного й стабільного позиціонування на конкурентному ринку. Провідні корпорації світу сьогодні визнають знання як основний економічний ресурс успіху і практикують різні підходи до управління знаннями. Науковці підтверджують, що «упровадження концепції управління знаннями у процес менеджменту підприємств має багатоаспектне прикладне значення, яке закладає об'єктивні передумови для набуття стійких конкурентних переваг у ринкових умовах господарювання» [8, с. 47].

Тому практичний досвід у поєднанні із теоретичними набутками науковців дає змогу окреслити основні аспекти управління знаннями в сучасних умовах, до яких відносимо: ідеологічний, організаційний, технологічний, культурологічний, інституційний, методологічний.

Ідеологічний аспект визначає мету управління знаннями в тактичному й стратегічному вимірах та відображає основну філософію причин і цілей управління знаннями. Управління знаннями здійснюється на основі концепції соціогуманістичного менеджменту, за якою знання стають особливою цінністю. Основу концепції становлять теоретичні надбання різних наукових шкіл, зокрема розвиток ресурсної теорії, теорії організаційної поведінки, інтелектуального капіталу. Відповідно до ресурсної теорії знання розглядають як внутрішній ресурс, який забезпечує конкурентні переваги на ринку. Автор терміна «менеджмент знань» К. Віінг також розглядав знання через призму ресурсного підходу, виділяючи у структурі знання активи знань, доступні для використання, та процеси формування, трансформації, зберігання інформації, що містить у собі знання [11].

У теорії організаційної поведінки знання пов’ язують iз процесом навчання, в т.ч. колективного навчання, тобто набуття знань, примноження знань, передачі знань, що сприяє формуванню людського капіталу. Важлива роль знанням відводиться і в концепціях інтелектуального капіталу, у структурі якого присутні знання, які здатні конвертуватися у вартість. Сучасні процеси інтелектуалізації суспільства та менеджменту, зокрема, підсилюють стратегічну функцію знання у цьому процесі, адже, «інтелектуалізуючись, системи менеджменту змінюються під впливом інтелекту, знань та IT, набуваючи нових якостей і властивостей» $[8$, c. 70$]$. Знання у структурі інтелектуального капіталу відіграють важливу роль у масштабах не лише окремої організації, але й національної економіки та підсилюють інтелектуальний потенціал держави. Зокрема, дослідник інтелектуальної проблематики в широкому контексті С. Вовканич у цьому зв'язку наводить розуміння інтелектуального потенціалу як можливості нагромаджувати, створювати і використовувати нові знання, проекти, ідеї, моделі й іншу семантичну інформацію, яка може стати інтелектуальною власністю України, сприяти їі прогресивній і міжнародній інтеграції як повноправного партнера [1].

Організаційний та технологічний аспекти висвітлюють практичний складник управління знаннями. Ці аспекти відображають особливості управління знаннями на всіх стадіях його життєвого циклу. Організаційний аспект передбачає налагодження процесу управління знаннями, зокрема, і через реструктуризацію організаційних структур, які вимагають змін. Зміни організаційного характеру повинні охоплювати створення відповідного підрозділу, наділеного функціональними обов'язками управління знаннями; запровадження нових посад-освітнього технолога, координатора та менеджера знань - і створення дорожньої карти ключових компетенцій, якими ці посадові особи повинні володіти. Створення дорожньої карти ключових компетенцій доцільно проводити на основі Рамкової програми оновлення ключових компетенцій, схваленої Європарламентом і Радою Свропейського Союзу у 2018 р., яка передбачає три типи обов'язкових навичок: технічних, аналітичних, комунікативних. Для успішної реалізації реструктуризаційних процедур управління знаннями дослідники пропонують створювати центр знань, під яким розуміють «критичний інтегрований ресурс підприємства, що включає бази даних, довідники, результати аудиту знань, спільноти, портали знань, навчальні матеріали, практичні рекомендації, резюме, та інші ресурси, які допомагають працівникам у знаходженні інформації і людей, що володіють необхідним знанням» [9, с. 262].

Технологічний аспект управління знаннями зорієнтований на вибір моделей та методів управління знаннями. 3 огляду на те, що в сутнісному наповненні категорії «знання» присутні інформаційні й когнітивістські елементи, відповідно, у технології управління знаннями поєднується інформаційна та психологічна група методів. Інформаційна група методів розширює джерела набуття знань, сприяє швидкому опрацюванню масиву інформації та іiі аналізу, забезпечує оптимальну процедуру зберігання, передавання й накопичення даних та інформації. Оскільки управління знаннями безпосередньо пов'язане з інформаційним середовищем, то для ефективного використання, поширення й генерування знань важливим $є$ створення баз даних, відповідних карт знань. Інформаційна взаємодія є необхідною складовою частиною в управлінні знаннями, а тенденції розвитку інформаційного суспільства й цифрової економіки підсилюють роль інформаційної групи методів. Синтез декількох галузей науки (психології, менеджменту, економіки, філософії) сприяв розвитку когнітивістського напряму в управлінні знаннями і поширенню методів технології управління знаннями на цій основі. Когнітивістські технології управління знаннями активно впливають на спосіб мислення, тому їх використовують на усіх стадіях життєвого циклу знання. Деякі моделі управління знаннями, зокрема модель екології управління знаннями Д. Сноудена, побудовані на когнітивній науці і охоплюють поділ знання на явне та неявне, активи знань; визначеність і невизначеність рішень стосовно цілей і причинних відносин, навіть такий тонкоплановий елемент, як віру. Усі інші моделі управління знаннями також використовують у своїх системах категорію явного й неявного знання, формалізованого й неформалізованого знання (Модель I. Нонака, Х. Такеучі «Спіраль знань», модель Л. Едвінсона, модель організації, заснованої на знаннях, Г. Хелдуна, модель К. Віінга та інші) $[6 ; 11 ; 12]$ та описують способи інтегрування індивідуальних знань у колективні.

Поєднання організаційного і технологічного аспектів засвідчує про формування організаційно-економічного механізму управління знаннями підприємства, 
який, на думку науковців, «повинен охоплювати всі економічні, законодавчо-нормативні, соціальні, психологічні та адміністративно-організаційні важелі, принципи і функції управління, організаційні структури та методи управління, інструменти забезпечення управління знаннями, інтелектуалізації трудової діяльності працівників засобами їхнього безперервного навчання, генерації й обміну знань та їх упровадження у виробництво» [9, с. 262]. Ефективне використання механізму уможливлюється завдяки синтезу класичних функцій менеджменту, які трансформуються у конкретні функції, такі як: модельне проектування з метою створення смарт-інновацій, організування спільнот знань та спільнот практики, відповідних інтелектуально наповнених просторів, у межах яких генеруються і примножуються нові знання.

Культурологічний аспект займає особливе місце у системі управління знанням, оскільки виникають питання етичного характеру, які окреслюють рівень доброчесності і відповідальності всіх учасників цього процесу в поєднанні із рівнем свободи творчості. Носієм знань є людина, яка має свою систему цінностей, поведінкових установок та мотивів, тому науковці підкреслюють, що «джерелом будь-якого знання $є$ людина, що потребує створення корпоративної культури, яка би спонукала працівників обмінюватися знаннями, що і $є$ організаційним складником системи управління знаннями» [7, с. 76]. Навіть моделі управління знаннями для успішної реалізації потребують відповідного середовища й організаційної культури, оскільки, продовжує дослідник, «відповідні моделі здатні існувати в мікроекономічному середовищі тих країн, під які вони розроблялися» [7, с. 76].

Однак знання мають також колективну природу, адже існує взаємозалежність знань, і кругообіг знання відбувається в певному розумовому просторі, об'єднуючи спільноти знань і спільноти практик, які повинні співпрацювати на основі довіри як особливої цінності. Довіра і відповідальність є складовими елементами культури, які повинні застерігати від недоброчесної поведінки й появи псевдознання. Тому у культурному полі вагому роль відіграє культура спільнодії, яка мотивує щиро ділитися вміннями і знаннями, трансформувати індивідуальні знання в колективні, формувати високий рівень мудрої колективної свідомості. Крім того, культурологічний чинник у системі управління знаннями проявляється також через комунікативну культуру, яка відображає здатність зберігати і передавати знання від покоління до покоління, зберігаючи спадковість знань. Таким чином поєднується принцип інноваційності, спрямований на примноження нових знань, і принцип традиційності, який витікає із специфіки національного менталітету.

Інституційний аспект відображає зрілість інституційного середовища, здатного підтримати на інституційному рівні формування ринку знань, якісного кадрового потенціалу; законодавчий захист права інтелектуальної власності; протікання процесів обміну, поширення, комерціалізації знань та інформації у правовому полі; зміцнення науково-дослідного сектору, а також забезпечення фінансової підтримки наукових проектів, які приносять суспільне благо. У межах цього аспекту формуються відповідні правила і норми співп- раці, чесні ринкові і нормативні умови управління знаннями. Швидке інтегрування віртуального і фізичного просторів приводить до появи цифрової інфраструктури як модерної інституції, що значно підсилює вагу інституційного аспекту.

В окрему групу доцільно виділити методологічний аспект для систематизації основних понять і впорядкування категоріального апарату, а також чіткого окреслення предмета вивчення як окремої галузі знань. Це важливо для збагачення наукової діяльності та розвитку наукового дискурсу. Науковий напрям управління знаннями розвивається в контексті єдиного простору менеджменту, інформації, психології, економіки, соціології та інших наук і $є$ продуктом історично складеної практики менеджменту та еволюційного розвитку економічних, соціальних та інших процесів. Однак управління знаннями має свою специфіку, зумовлену особливостями категорії «знання», тому необхідно визначити критерії його виокремлення з єдиної системи менеджменту як автономного наукового знання.

3 огляду на окреслені аспекти управління знаннями, перед теоретиками і практиками постають завдання, спрямовані на активізацію процесів створення інтелектуальних організацій, які працюватимуть завдяки власному інтелектуальному ресурсу, а не запозиченому; активнішого використання знань для пожвавлення інноваційного розвитку вітчизняної економіки та створення суспільного блага; підвищення рівня доброчесності й відповідальності перед суспільством; забезпечення екологічної чистоти інноваційних продуктів; використання знань для розвитку соціальних проектів; розроблення мотиваційного механізму, здатного стимулювати трансформацію й обмін знаннями.

Висновки. Реалії сьогодення засвідчують, що фінансово успішні кор-порації світу в своєму стратегічному розвитку особливу роль відводять знанням, причому звертаючи увагу не на споживання наявного знання, а на створення нового, яке, створюючи додану вартість, примножує інтелектуальний капітал і зміцнює конкурентоспроможний потенціал. 3 огляду на це, пріоритетними стають інвестиції в людський фактор як носія знань, а управління знаннями виокремлюється як особлива функція менеджменту. У системі управління знаннями присутні стратегічні й тактичні цілі, поєднання яких забезпечує інноваційність розвитку економіки на основі знань та формування нових компетенцій персоналу відповідно до тенденцій ринку. Цілісність дослідження управління знаннями як категорії, окремої функції менеджменту, процесу та явища досягається оптимальним поєднанням всіх аспектів: ідеологічного, організаційно-технічного, культурологічного, інституційного і методологічного.

Усі аспекти управління знаннями є важливими, однак рівень теоретич-ного опрацювання та прикладного використання є різним. 3 огляду на це, необхідно продовжувати наукові пошуки у плані як концептуалізації понять, так і розроблення сучасних механізмів управління знаннями, здатних працювати в кіберфізичному просторі. У прикладному сенсі доцільно розробляти підходи до оцінювання корисності знань та їхньої частки у створенні нової вартості; дослідження технологій формування та застосування знань у реальних умовах у режимі реального часу. 


\section{Список використаних джерел:}

1. Вовканич С.Й. Духовно-інтелектуальний потенціал України та їі національна ідея. Львів. Видавництво ЛБА, 2001. 540 с.

2. Захарчин Г.М., Космина Ю.М. Інтелектуальна культура в системі управління знаннями. Причорноморські економічні cmудіï, 2018.Вип. 27, ч. 1. С. 129-133.

3. С.М. Ілляшенко, Ю.С. Шипуліна, Н.С. Ілляшенко, Г.О. Комарницька. Управління знаннями в системі інноваційного розвитку організації. Маркетинг і менеджмент інновацій, 2017, № 1. С. 231-238.

4. Мартиненко М.В. Управління організаційними знаннями підприємства: теоретичний аспект: монографія. Харків: ІНЖЕК, 2013. - $218 \mathrm{c}$.

5. Наливайко А.П. Стратегічне управління знаннями підприємства: монографія / А.П. Наливайко О.М. Гребешкова, Л.П. Батенко та ін. - К.: КНЕУ, 2014. - 445 с.

6. Нонака И. Компания - создатель знания. Зарождение и развитие инноваций в японских фирмах / И. Нонака, Х. Такеучи. Пер. с англ. А. Трактинского. - М.: ЗАО «Олимп Бизнес», 2011. -384 с.

7. Руденко М.В., Криворучко В.О. Управління знаннями як конкурентна перевага підприємства. Економіка та держава. 2016. № 4. С. 74-78.

8. Ситник Й.С. Інтелектуалізація систем менеджменту підприємств: концепція, системний моніторинг та моделювання: монографія. Львів: Видавництво Львівської політехніки, 2017. - 380 с.

9. Токмикова I.В., Войтов I.М., Діденко Я.В. Розвиток технологій управління знаннями на підприємствах. Менеджмент $i$ маркетинг. Вісник економіки транспорту і промисловості. № 60. 2017. С. 258-264.

10. Шавкун І.Г., Дибчинська Я.С. Управління організаційними знаннями: підходи до розуміння сутності. Гуманітарний вісник ЗДІА. 2013. № 53. С. 185-192.

11. Wiig K. Knowledge Management: An Introduction and Perspective / K. Wiig // Journal of Knowledge Management. - 1997. Vol.1. - Iss:1, P. 6-14.

12. Edvinsson L. Intellectual Capital: realizing your company's true value by fi nding its hidden brainpower (1sted.) / L. Edvinsson, M. Malone. - N.Y.: Harper Business, 1997. - 230 p.

1. Vovkanych S.J. (2001) Dukhovno-intelektualnyi potentsial Ukrainy ta yii natsionalna ideia [Spiritual and intellectual potential of Ukraine and its national idea]. Lviv: LBA Publishing House. (in Ukrainian)

2. Zaxarchy`n G.M., Kosmyna Yu.M. (2018) Intelektualna kultura v systemi upravlinnia znanniamy [Intellectual culture in the knowledge management system]. Black Sea Economic Studies, vol. 3, no. 1, pp. 129-133.

3. Illiashenko S.M., Shypulina Yu.S., Illiashenko N.S., Komarnytska H.O. (2017) Upravlinnia znanniamy v systemi innovatsiinoho rozvytku orhanizatsii [Knowledge management in the system of innovative development of the organization]. Marketing and innovation management, no. 1, pp. 231-238.

4. Martynenko M.V. (2013) Upravlinnia orhanizatsiinymy znanniamy pidpryiemstva: teoretychnyi aspekt: monohrafia [Management of organizational knowledge of the enterprise: theoretical aspect: monograph]. Kharkiv: INZhEK. (in Ukrainian)

5. Nalyvaiko A.P. (2014) Stratehichne upravlinnia znanniamy pidpryiemstva: monohrafiia [Strategic management of enterprise knowledge: a monograph]. Kyiv: KNEU. (in Ukrainian)

6. Nonaka I. (2011) Kompaniya - sozdatel' znaniya. Zarozhdenie i razvitie innovatsiy v yaponskikh firmakh [The company is the creator of knowledge. Origin and development of innovations in Japanese companies]. Moscow: CJSC "Olymp Business". (in Russian)

7. Rudenko M.V., Kryvoruchko V.O. (2016) Upravlinnia znanniamy yak konkurentna perevaha pidpryiemstva [Knowledge management as a competitive advantage of the enterprise]. Economy and state, no. 4 pp. 74-78.

8. Sytnyk Y.S. (2017) Intelektualizatsiia system menedzhmentu pidpryiemstv: kontseptsiia, systemnyi monitorynh ta modeliuvannia: monohrafiia [Intellectualization of enterprise management systems: concept, system monitoring and modeling: monograph]. Lviv: Lviv Polytechnic Publishing House. (in Ukrainian)

9. Tokmykova I.V., Voitov I.M., Didenko Ya.V. (2017) Rozvytok tekhnolohii upravlinnia znanniamy na pidpryiemstvakh [Development of knowledge management technologies in enterprises]. Management and marketing. Bulletin of Transport Economics and Industry, no. 60, pp. 258-264.

10. Shavkun I.H., Dybchynska Ya. S. (2013) Upravlinnia orhanizatsiinymy znanniamy: pidkhody do rozuminnia sutnosti [Organizational knowledge management: approaches to understanding the essence]. Humanitarian Bulletin ZDIA, no. 53, pp. 185-192.

11. Wiig K. Knowledge Management: An Introduction and Perspective / K. Wiig // Journal of Knowledge Management. - 1997. Vol.1. - Iss:1, P. 6-14.

12. Edvinsson L. Intellectual Capital: realizing your company's true value by fi nding its hidden brainpower (1sted.) / L. Edvinsson, M. Malone. - N.Y.: Harper Business, 1997. -230 p. 
Zakharchyn Halyna, Lyubomudrova Nadiya, Panas Yaroslav

Lviv Polytechnic National University

\section{MAIN ASPECTS OF KNOWLEDGE MANAGEMENT IN MODERN CONDITIONS}

The era of intellectual and information economy is filled with new content and revision of technologies and management tools. In this context, the factors of innovative economic development and increasing intellectual potential are changing. Modern challenges raise the issue of finding and rethinking the sources of economic growth and increasing the competitiveness of enterprises. As today's successful corporations around the world, which are innovative leaders, are strategically focused on the development of the knowledge economy, the issue of knowledge management is becoming a priority. These issues should be addressed comprehensively, both at the theoretical and practical levels, because only through a combination of theoretical aspects of research with practice, the transformation of knowledge into the intellectual potential of the organization is achieved and its innovative capacity increases. Thus, the purpose of the article is to systematically cover the main aspects of knowledge management in modern reality, which include: ideological, organizational, technological, cultural, institutional, methodological ones. To reveal the content of the article, general methodological approaches were used, in particular, synthesis and analysis, a systematic approach - for an essential understanding of knowledge management as a category and process and a systematic presentation of its main aspects; historical method - to consider knowledge management in the context of the evolutionary development of theories and concepts; generalization - for an objective assessment of the theoretical achievements of domestic and foreign scientists in the field of the outlined problem. Methodological principles of objectivity were also important for the analysis of the subject of research in order to determine the factors influencing the transformation of individual knowledge into collective one and complexity - to reveal the multifaceted aspects of knowledge management and outline new tasks in the context of new challenges. An important result is the development of theoretical approaches to the coverage of the content-functional form of manifestation of knowledge management at all stages of the life cycle through the disclosure of the main aspects of knowledge management. The practical component of the achieved result is aimed at finding effective knowledge management models capable of working in real time, and the creation of intellectual organizations that can combine the formation of new knowledge, smart technologies with the expansion of staff competencies. The practical value of the article is to develop and supplement the provisions aimed at in-depth coverage of the essential understanding of knowledge management and its role in ensuring competitive advantage and innovative economic development. In the applied sense, the described organizational and technological aspects of knowledge management are important.

Key words: knowledge, knowledge management, knowledge generation, knowledge management models, innovation, competencies, intellectualization.

JEL classification: D80, D83, H41 